J. Dhaka National Med. Coll. Hos. 2012; 18 (01): 34-38

\title{
Gross and histomorphological study of thickness of the gallbladder wall
}

\author{
Laila Farzana Khan ${ }^{1}$, Humaira Naushaba ${ }^{2}$, Uttam kumar paul $^{3,}$ \\ Shibani Banik, ${ }^{4}$ Mostak Ahmed Al-Zafri ${ }^{5}$
}

\begin{abstract}
${ }^{1}$ Senior Lecturer, Department of Anatomy, Dhaka National Medical College, Dhaka, ${ }^{2}$ Professor and Head, Department of Anatomy, Sir Salimullah Medical College, Dhaka, ${ }^{3}$ Assistant Professor, Department of Anatomy, Sir Salimullah Medical College, Dhaka, ${ }^{4}$ Associate Professor, Department of Anatomy, Dhaka National Medical College, Dhaka, ${ }^{6}$ Curator, Department of Anatomy, Dhaka National Medical College, Dhaka.
\end{abstract}

\begin{abstract}
:
Diffuse gallbladder wall thickening is a nonspecific alteration caused by both intrinsic and extracholecystic diseases. The incidence of gallbladder illness in our country increasing day by day. Details morphological and histomorphological knowledge is essential for proper diagnosis \& management of the gallbladder diseases. This is a cross sectional descriptive type of study which was carried out in the Department of Anatomy, Sir Salimullah Medical College, Dhaka from July 2010 to June 2011. The number of sample was 62 postmortem human gallbladder which were collected from unclaimed dead bodies of the morgue of Dhaka Medical College and Sir Salimullah Medical College. The samples were divided into three different age groups. Morphological study was carried out on all samples by fine dissection method and histomorphological study was carried out on 18 relatively fresh samples by light microscopic method. There was statistically significant difference found when values were compared between different age groups. This study has revealed an age related change in the thickness of the gallbladder wall.
\end{abstract}

Key words: Gallbladder, thickness, aging

\section{INTRODUCTION:}

The gallbladder is a hollow pear-shaped sac which acts as a reservoir \& concentrator of bile. In living body it is slate blue in colour, lies in a non-peritoneal fossa on the inferior surface of the right lobe of the liver'. Thickness of the gallbladder wall is about $3 \mathrm{~mm}$ or less ${ }^{7}$. The wall of the gallbladder consists of (from inner to outer), i) a highly folded mucosa with a simple columnar epithelium \& lamina propria, ii) a thin fibromuscular layer, iii) perimuscular connective tissue layer and iv) an external adventitia or serosa $^{1}$. Gallbladder problems are common worldwide \& this is one of the commonest clinical problems encountered in our daily practice in Bangladesh. The incidence of these diseases rises with advancing age ${ }^{\mathbf{1 0}}$. Gallbladder diseases are diagnosed clinically and confirmed by various non invasive as well as invasive procedures and wall thickness is the most important indicator to diagnose such diseases. Therefore full knowledge about gross and histomorphological features of thickness of the gallbladder wall has hard fast implication for the investigation, diagnosis and further management procedure. The present study was performed to find out the gross \& histomorphological feature and age related changes of the gallbladder wall.

\section{MATERIALS \& METHODS:}

This was a cross sectional descriptive study carried out in the Department of Anatomy, Sir Salimullah Medical College (SSMC), Mitford, Dhaka. The study was conducted from July 2010 to June 2011. The number of samples was 62 postmortem human gallbladder which were collected from unclaimed dead bodies that were under examination in the department of Forensic Medicine of Dhaka Medical College, Dhaka and Sir Salimullah Medical College (SSMC), Dhaka.

The samples were divided into three age groups i.e. group A (10-20 years), group B (21-40 years) and group C (41-70 years) (Table 1). Morphological study was carried out on all samples and histomorphological study was carried out on 18 relatively fresh samples.

Table-1: Age distribution of different study groups (according to Sarkar ${ }^{8}, 2010$ ) 


\begin{tabular}{lll}
\hline Group & $\begin{array}{c}\text { Age range } \\
\text { (years) }\end{array}$ & $\begin{array}{c}\text { No. of } \\
\text { samples } \\
(\mathbf{n}=62)\end{array}$ \\
\hline A & 14 & $10-20$ \\
B & 30 & $21-40$ \\
C & 18 & $41-70$ \\
\hline
\end{tabular}

\section{Morphological study:}

The thickness of the gallbladder wall was measured by fine dissecting method. A longitudinal incision was made by sharp B-P blade through the peritoneal smooth surface of the gallbladder from fundus to neck and interior of the gallbladder was cleaned with jets of tap water. Then the thickness of wall of the gallbladder was measured in $\mathrm{mm}$ at the maximum transverse diameter of the fundus, body \& neck region of the gallbladder with the help of digital slide caliper (Fig 1). For taking measurements the non peritoneal surface was not chosen due to rough and irregular surface.

\section{Histomorphological study:}

Histomorphological study was carried out on 18 relatively fresh samples (six samples from each group) by light microscopic method. After collection the samples were fixed in formol saline solution. For tissue block, pieces of tissue measuring approximately $1 \mathrm{~cm} \times 1 \mathrm{~cm} \times$ whole thickness were taken from the peritoneal wall of the fundus, body $\&$ neck region of the gallbladder. Then the tissue blocks were refixed in Carnoy's fluid in a plastic container. The tissues were washed in running tap water, dehydration was done with ascending grades of alcohol, cleared with xylene, infiltrated and embedded in paraffin. Paraffin blocks were cut at $5 \mu \mathrm{m}$ thickness and stained with MalloryHeidenhains aniline blue (Mallory-Azan) stain. Three slides were prepared from each sample. Thus a total of $6 \times 3=18$ histological slides were made from each group. Finally $18 \times 3=54$ slides were prepared for the whole study. For studying the total thickness of all the layers of the gallbladder wall, a transparent sheet was placed over the glass slide and a rectangular area around the tissue section was drawn by fine marker pen. The rectangular area was divided into three equal areas by drawing transverse line at right angle to the long axis of the tissue section by fine marker black colour pen. The mid points of the each area were marked by another fine marker green colour pen. Then the transparent sheet was cut along the rectangular area and it was placed over the tissue section \& fixed with adhesive tape. Then the total thickness of the fundus, body \& neck of the gallbladder was measured in $\mu \mathrm{m}$ at the mid point of the three divisions by ocular micrometer. Mean of these three readings were calculated. The ocular micrometer calibration was superimposed on stage micrometer in such a way that the starting mark on the ocular micrometer matches exactly with the starting mark on the stage micrometer. Then the marker on the stage micrometer and ocular micrometer that corresponds to each other most closely was noted. In this way, determination of how many number of smallest division of the ocular micrometer corresponded to the number of smallest division of the stage micrometer was done (Fig 2).

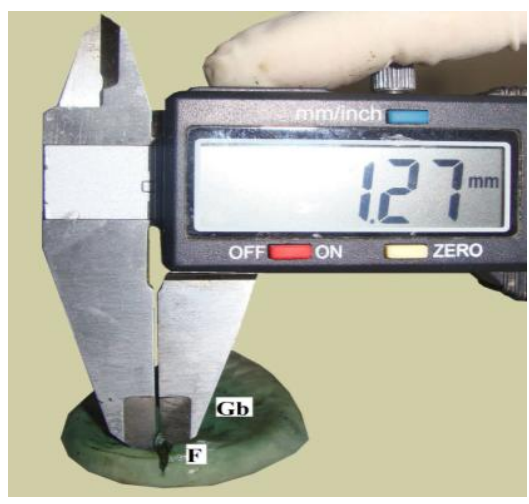

A
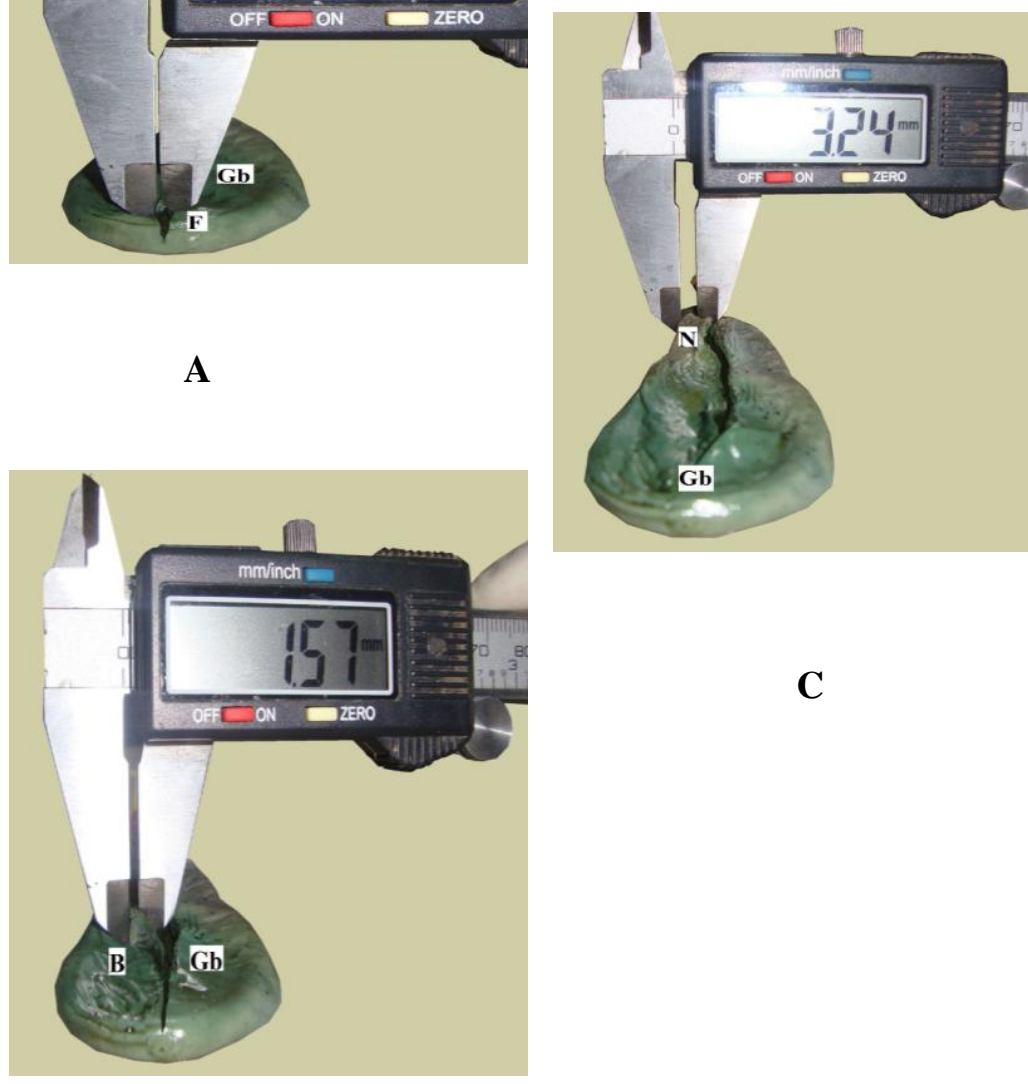

B

1: Figure shows measurement of thickness of wall of the gallbladder at fundus (A), body (B) and neck (C) region with the help of digital slide caliper. 


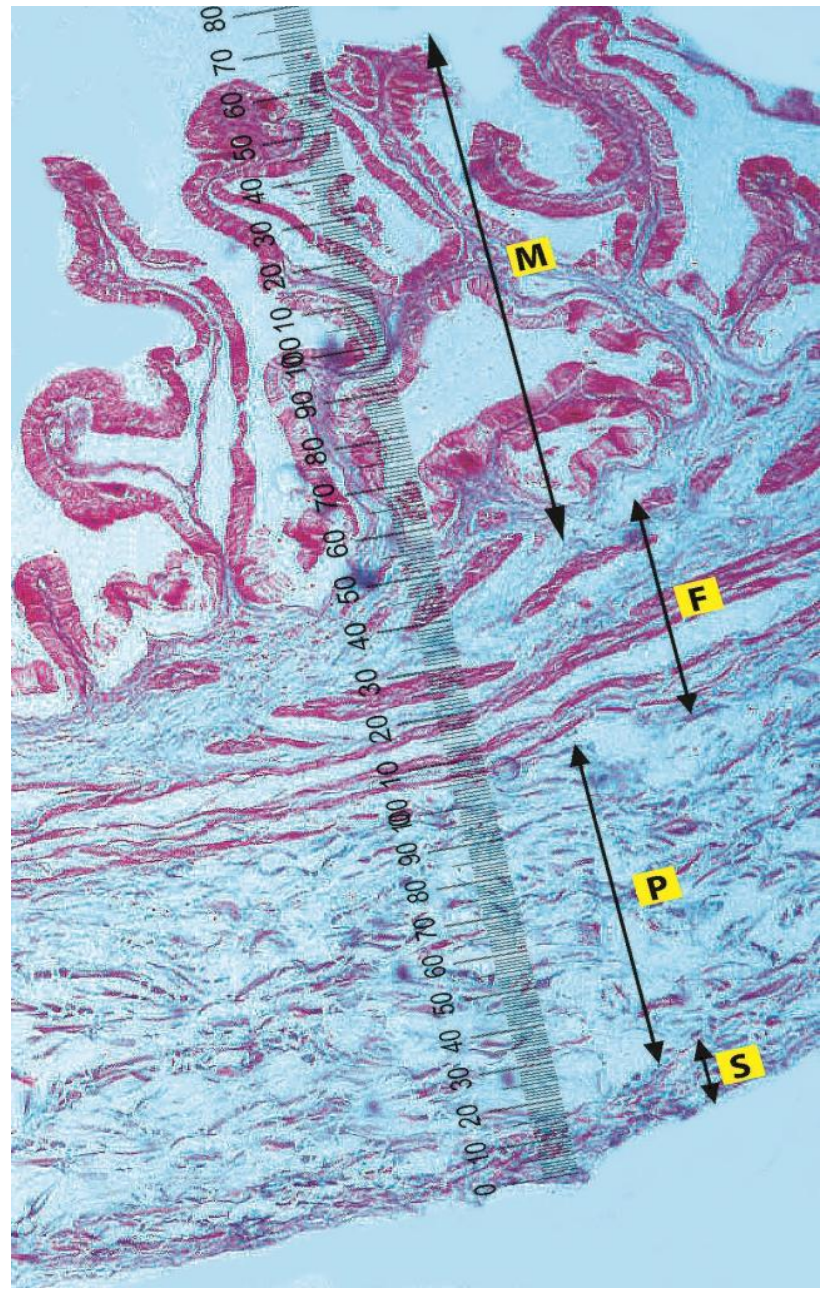

Fig 2 Photomicrograph of wall of the gallbladder showing the measurement of the total thickness of the gallbladder wall with the help of ocular micrometer.

Stain: Mallory-Azan under low power of magnification (10x). M-mucosa,

F-fibromuscular layer, P-perimuscular layer, Sserosa

RESULTS: In the present study, morphologically the mean $( \pm$ SD) thickness of the gallbladder wall at fundus were $1.47 \pm 0.06 \mathrm{~cm}$ in group $\mathrm{A}, 1.57 \pm 0.05 \mathrm{~cm}$ in group $\mathrm{B} \& 1.61 \pm 0.04 \mathrm{~cm}$ in group $\mathrm{C}$, at body were $1.67 \pm 0.10 \mathrm{~cm}$ in group $\mathrm{A}, 1.76 \pm 0.04 \mathrm{~cm}$ in group $\mathrm{B} \& 1.79 \pm 0.04 \mathrm{~cm}$ in group $\mathrm{C}$ and at neck were 3.09 $\pm 0.05 \mathrm{~cm}$ in group A, $3.22 \pm 0.06 \mathrm{~cm}$ in group B \& $3.25 \pm 0.04 \mathrm{~cm}$ in group $\mathrm{C}$. The differences of thickness of the gallbladder wall at fundus were highly significant $(\mathrm{p}<0.001)$ between A vs $\mathrm{B}$, highly significant $(\mathrm{P}<0.001)$ between A vs $\mathrm{C} \&$ significant $(\mathrm{P}<0.05)$ between $\mathrm{B}$ vs $\mathrm{C}$, at body were highly significant $(p<0.001)$ between A vs $B$, highly significant $(\mathrm{P}<0.001)$ between $\mathrm{A}$ vs $\mathrm{C}$ \& not significant $(\mathrm{P}>0.10)$ between $\mathrm{B}$ vs $\mathrm{C}$ and at neck were highly significant $(\mathrm{P}<0.001)$ between $\mathrm{A}$ vs $\mathrm{B}$, highly significant $(\mathrm{P}<0.001)$ between $\mathrm{A}$ vs $\mathrm{C} \&$ significant $(\mathrm{P}<0.05)$ between $\mathrm{B}$ vs $\mathrm{C}$. The correlation between age and thickness of the gallbladder wall showed that the positive correlation exists at fundus $(\mathrm{r}=+0.702$, $\mathrm{P}<0.001)$, body $(\mathrm{r}=+0.544, \quad \mathrm{P}<0.001)$ and neck $(\mathrm{r}=+0.573, \quad \mathrm{P}<0.001)$ which was found highly significant (Table $2 \& 3$ and Fig 3A \& 3C). Histomorphologically, The mean $( \pm$ SD) total thickness of all the layers of the gallbladder at fundus were $1371 \pm 58.31 \mu \mathrm{m}$ in group A, $1546.93 \pm 51.46 \mu \mathrm{m}$ in group B \& $1551.19 \pm 44.22 \mu \mathrm{m}$ in group $\mathrm{C}$, at body were $1543.73 \pm 75.42 \mu \mathrm{m}$ in group $\mathrm{A}, 1746.99 \pm 43.18$ $\mu \mathrm{m}$ in group B \& $1753.15 \pm 37.87 \mu \mathrm{m}$ in group $\mathrm{C}$ and at neck were $3028.87 \pm 79.56 \mu \mathrm{m}$ in group A, $3222.10 \pm 113.07 \mu \mathrm{m}$ in group B \& 3299.64 \pm 119.74 $\mu \mathrm{m}$ in group $\mathrm{C}$. The differences of total thickness of all the layers of the gallbladder at fundus were highly significant $(\mathrm{P}<0.001)$ between $\mathrm{A}$ vs $\mathrm{B}$, highly significant $(\mathrm{P}<0.001)$ between $\mathrm{A}$ vs $\mathrm{C}$ and not significant $(\mathrm{P}>0.05)$ between $\mathrm{B}$ vs $\mathrm{C}$, at body were highly significant $(\mathrm{P}<0.001)$ between $\mathrm{A}$ vs $\mathrm{B}$, highly significant $(\mathrm{P}<0.001)$ between $\mathrm{A}$ vs $\mathrm{C} \&$ not significant $(\mathrm{P}>0.05)$ between $\mathrm{B}$ vs $\mathrm{C}$ and at neck were significant $(\mathrm{P}<0.05)$ between $\mathrm{A}$ vs $\mathrm{B}$, significant $(\mathrm{P}<0.01)$ between $\mathrm{A}$ vs $\mathrm{C} \&$ not significant $(\mathrm{P}>0.10)$ between B vs C (Table $4 \& 5$ and Fig 3B).

Table-2: Mean $( \pm \mathrm{SD})$ thickness of the gallbladder wall at fundus, body and neck region in different age groups (Morphological study) Thickness in mm (Mean \pm SD)

\begin{tabular}{clll}
\hline $\begin{array}{c}\text { Age } \\
\text { grou } \\
\mathrm{p}\end{array}$ & $\begin{array}{c}\text { At } \\
\text { fundus }\end{array}$ & At body & At neck \\
& & & \\
\hline A & $1.47 \pm 0$. & $1.67 \pm 0$ & $3.09 \pm$ \\
B & 06 & .10 & 0.05 \\
C & $1.57 \pm 0$. & $1.76 \pm 0$. & $3.22 \pm 0$ \\
& 05 & 04 & .06 \\
& $1.61 \pm 0$. & $1.79 \pm 0$. & $3.25 \pm 0$ \\
& 04 & 04 & .04 \\
& & & \\
\hline
\end{tabular}


J. Dhaka National Med. Coll. Hos. 2012; 18 (01): 34-38

Table-3: Comparison of $\mathrm{P}$ value in different age groups (Morphological study)

\begin{tabular}{|c|c|c|c|}
\hline & P value & $P$ value & $P$ value \\
\hline A vs $B$ & $0.0001^{* * * *}$ & $0.0001^{* * *}$ & $0.0001^{* * * *}$ \\
\hline A vs $C$ & $0.0001^{* * *}$ & $0.0001^{* * *}$ & $0.0001^{* * *}$ \\
\hline B vs C & $0.012^{*}$ & $0.123^{\mathrm{ns}}$ & $0.039^{*}$ \\
\hline
\end{tabular}

Table-4: Mean ( \pm SD) total thickness of all the layers of the gallbladder at fundus, body and neck region in different age groups (Histomorphological study)

$$
\text { Total thickness in mm (Mean } \pm \text { SD) }
$$

\begin{tabular}{clll}
$\begin{array}{l}\text { Age } \\
\text { group }\end{array}$ & At fundus & At body & At neck \\
\hline A & $1371 \pm 58.31$ & $1543.73 \pm 75.42$ & $3028.87 \pm 79.56$ \\
B & $1546.93 \pm 51.46$ & $1746.99 \pm 43.18$ & $3222.10 \pm 113.07$ \\
C & $1551.19 \pm 44.22$ & $1753.15 \pm 37.87$ & $3299.64 \pm 119.74$
\end{tabular}

Table-5: Comparison of $\mathrm{P}$ value in different age groups

Histomorphological study)

\begin{tabular}{|c|c|c|c|}
\hline & $P$ value & $P$ value & P value \\
\hline A vsB & $0.0001^{\text {\%**** }}$ & $0.0001^{\text {s*** }}$ & $0.047^{*}$ \\
\hline A vs $\mathrm{C}$ & $0.0001^{* * * *}$ & $0.0001^{* * * *}$ & $0.008^{* * *}$ \\
\hline $\mathrm{B}$ vs $\mathrm{C}$ & $0.888^{\mathrm{ns}}$ & $0.848^{\mathrm{ns}}$ & $0.399^{\mathrm{ns}}$ \\
\hline
\end{tabular}

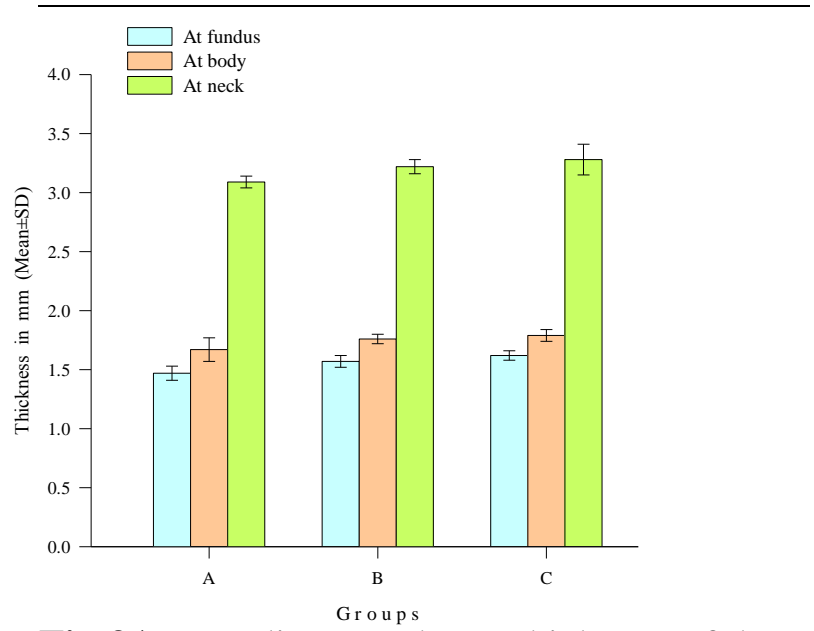

Fig 3A: Bar diagram shows thickness of the gallbladder wall at fundus, body $\&$ neck region in different age groups. (Morphological study)

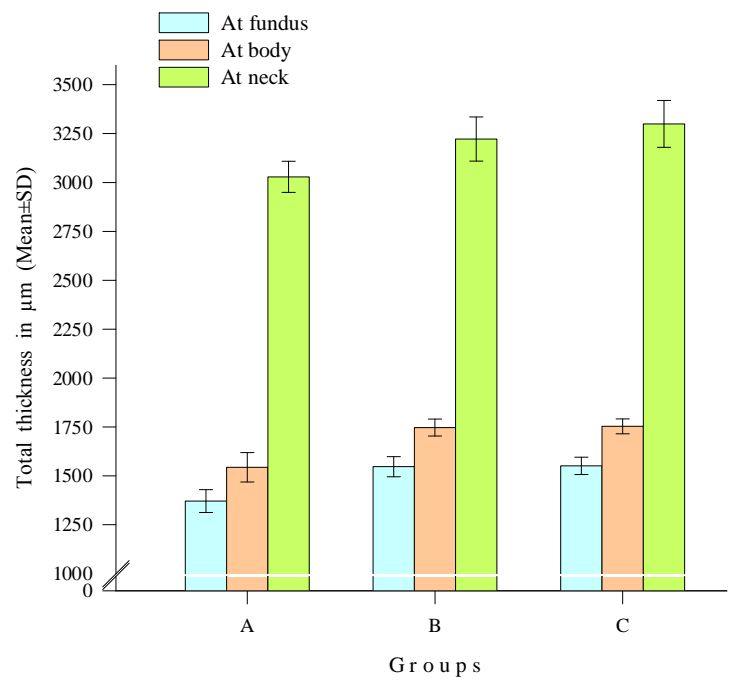

3B

Fig 3B: Bar diagram shows total thickness of all the layers of the gallbladder wall at fundus, body $\&$ neck region in different age groups. (Histomorphological study)

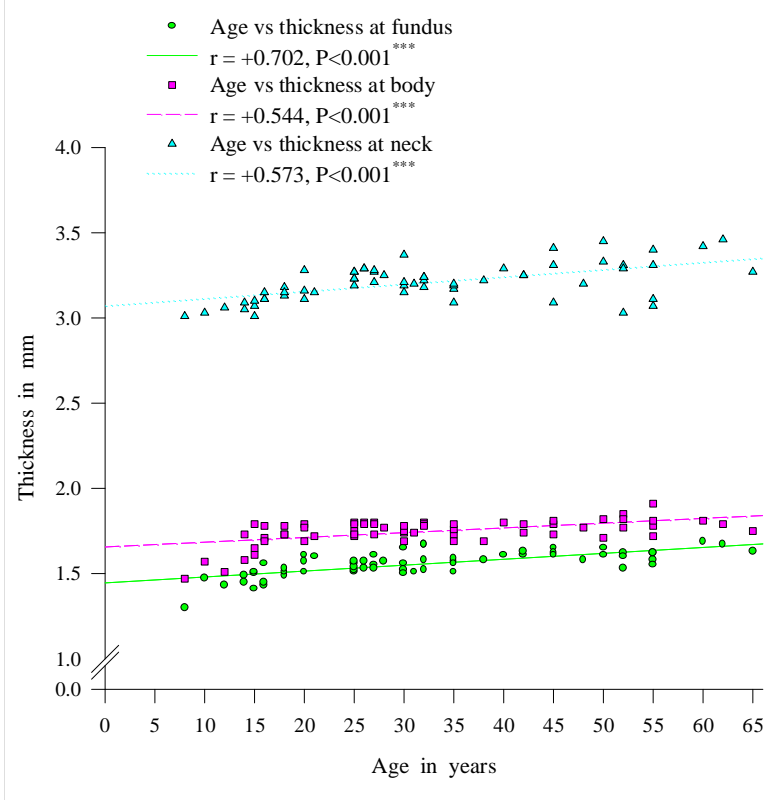

\section{C}

Fig 3C: Figure shows correlation between age and thickness of the gallbladder wall at different site in different age groups 


\section{DISCUSSION:}

In the present study, morphologically the highest mean thickness of the gallbladder wall at fundus, body \& neck region was found in group $\mathrm{C}$, whereas the lowest mean thickness was found in group A. The values of the mean thickness of the gallbladder wall at fundus, body \& neck region were highly significant $(\mathrm{P}<0.001)$ when group $\mathrm{A}$ was compared with group B and group A was compared with group C. It showed positive correlationship with age at fundus, body \& neck region which was highly significant $(\mathrm{P}<0.001)$. The mean thickness of the gallbladder wall at fundus, body and neck in adult age group were also nearly similar with the measurements of Khalil ${ }^{4}$ (1993). He found that the mean thickness of the gallbladder wall at fundus, body \& neck region were $1.57 \mathrm{~mm}, 1.72 \mathrm{~mm}$ and $3.23 \mathrm{~mm}$ respectively in 25 to 50 years age group. The result of the present study consistent with the values of different text books edited by Goldberg ${ }^{3}$ (1993), Meire \& Cosgrove ${ }^{6}$ (2001) and Rumack \& Wilson $^{7}$ (2005). The values of the study of Engel JM ${ }^{1}$ in 2006 and Loreno $\mathrm{M}$ et $\mathrm{al}^{5}$ in 2009 also similar with the result of the present study.

\section{CONCLUSION:}

There were changes in the gross and histomorphology of the thickness of the gallbladder wall in relation to age in this study. To establish a standard data similar study with larger sample size in different age groups and using more advance methods including both sexes are recommended.

\section{REFERENCES:}

1. Engel JM, Deitch EA, Sikkema W. Gallbladder wall thickness sonographic accuracy and relation to disease. AJR 2006 May; 134(4): 907

2. Eroschencko VP. diFiore's atlas of histology with functional correlations. $10^{\text {th }}$ ed. Baltimore: Williams and Wilkins, 2005: p. 283

3. Goldber B. Textbook of abdominal ultrasound. Baltimore: Williams \& Wilkins; 1993. p. 129

4. Khalil M. A comparative anatomical study of the extra hepatic biliary apparatus in goat, cow and men (M Phil thesis). Dhaka: University of Dhaka

5. Loreno M, Travali S, Bucceri AM, Scalise G, Vergilo C, Brogna A. Ultrasonogaphic study of gallbladder wall thickness and emptying in cirrhotic patient without gallstones. Gastroenterology research and practice June 200929 (2): 1-4

6. Meire H, Cosgrove D, Dewbury K, Farrant P. (Clinical ultrasound a comprehensive text abdominal and general ultrasound vol 1). $2^{\text {nd }}$ ed. London: Churchill Livingstone; 2001. p. 314

7. Rumack C, Wilson S, Charbone J. Diagnostic ultrasound. $3^{\text {rd }}$ ed. Missouri: Mosby; 2005. p. 1234-6

8. Sarkar N. Role of ultrasonography in the diagnosis of common gallbladder problems (M Phil thesis). Dhaka: Bangabandhu Sheikh Mujib Medical University. 2010.

9. Standring S. Gray's anatomy the anatomical basis of clinical practice. $40^{\text {th }}$ ed. London: Churchill Livingstone; 2008. p. 1177-81

10. Williams NS, Bulstrode CJK, O'connel PR. Bailey \& Love's short practice of surgery. $25^{\text {th }}$ ed. London: Hodder Arnold; 2008.p. 1117 